\title{
The Impact of Peaceful Life Skills Oriented Education Program on Social Adaptation and Skills of Preschool Children
}

\author{
Hikmet Zelyurt ${ }^{1, *}$, Ferda Göktürk İnce ${ }^{2}$ \\ ${ }^{1}$ Department of Education, College of Primary Education, Preschool Teaching Department, Inonu University, Malatya, Turkey \\ ${ }^{2}$ Teacher Hazım Ersu Primary School, Istanbul, Turkey
}

Copyright $\bigcirc 2018$ by authors, all rights reserved. Authors agree that this article remains permanently open access under the terms of the Creative Commons Attribution License 4.0 International License

\begin{abstract}
The present study was conducted to investigate the effect of the Peaceful Life Skills Education Program on the social adaptation and skills of pre-school children. In the study, semi-experimental model with pretest and posttest control groups was used. The study sample included fifty 5-year-old students attending Malatya Civil Servants Kindergarten during the 2013-2014 academic year. The study group and control group included 25 students each. The Social Adaptation and Skills Scale and a Personal Information Form developed by Işık (2007) were used as data collection instruments. The study group students were instructed with the Peaceful Life Skills-Based Education Program developed by the author, one hour per week for 12 weeks. The control group students were instructed based on the conventional curriculum. Data analysis was conducted with the t-test. The study results demonstrated that the implemented education program had a positive effect on social adaptation and skills of preschool children.
\end{abstract}

Keywords Preschool, Social Adaptation, Social Skills, Peace, Peace Education

\section{Introduction}

Violence and terrorism, prevalent in modern daily life, destroy the sense of peace and security and this insecure environment even risks the development of young children. Unfortunately, despite century's long efforts, humankind was not able to achieve a lasting peace. On the issue, philosopher author Umberto Eco wrote the following: "After the Great Wars, wars were not removed from the world of the 21 st century despite all expectations. On the contrary, today, wars are prevalent and diversified. If peace education is not a new concept, why such education has not been successful in the past? How can we make a difference in peace through education in the 21 st century?" Eco also emphasized that it is very difficult to achieve universal peace, however even a minor peace can reduce tensions and a series of minor peace may lead to a reduction of tensions that feed the endless war (Pinar and Acar, 2012).

Undoubtedly, the mentioned "series of minor peace" would only be possible with the development of individuals' universal values. Universal values such as love, respect, equality, justice, tolerance, empathy, cooperation, solidarity, resolving conflicts with non-violent methods, embracing all the people of the world and the nature with love constitute the content of peace education. Peace education, which is considered as a requirement for peace and the establishment of a culture of peace, is a phenomenon that should definitely be instructed to students, especially today, as the physical violence has penetrated schools. It is necessary for children to attend the Peace Education Program from early ages and to assist others to learn about the skills involved in this program (Tapan, 2006). According to Mahatma Gandhi, if true peace is desired, it should start with children. Ibrahim Issa emphasized the importance of teaching the concept of peace at early ages by stating that peace and democracy education should be provided to babies in their mother's milk (Noe, 2008, cited by Aktas and Safran, 2013, p. 137). It is important to start the social change in schools for the creation of a peaceful culture based on equality, justice, democracy, human rights, tolerance and solidarity in the society, because schools and teachers are the most important elements that would initiate this change through peace education (Demir, 2011). Timothy Reagan stated that "Peace is our future and peace education is the key instrument in reaching the future" (Dinçer, 2012, p. 36). A bright and promising future would be possible by training children who recognize the value of peace, love, sharing and friendship and reflect universal values.

In order to achieve the goals of peace education, it is necessary to develop an adequate curriculum for peace culture, to author adequate textbooks, to develop and implement special programs, and to train qualified teachers. In order to create a world of peace and tolerance, multicultural programs that aim to recognize and accept the 
differences should be developed, implemented and assessed.

The general objective of the present study was to investigate the impact of the Peaceful Life Skills Education Program instruction on social adaption and skills of pre-school children.

\section{Methodology}

In this study, an empirical model was used since the study aimed to investigate the effect of the Peaceful Life Skills Education Program on social adaptation and skills of pre-school children. Since the study group was not determined by random selection, the study was conducted with the semi-experimental model with pre-test and post-test and control group. Measurements were conducted for all groups before and after the instructions. The study group was instructed with the education program specially developed by the researcher, while the control group was instructed with the regular program.

\subsection{Participants}

The study was conducted with students attending Ministry of National Education, Civil Servants Kindergarten, which is an independent kindergarten, in Malatya province central district during the 2013-2014 academic year. Thus, necessary authorizations were obtained from the National Education Provincial Directorate. Only 2 of the 8 classes in the school were selected and one was considered as the study and the other was considered as the control group.

Fifty students, 25 in the study group and 25 in the control group, participated in the study. All 50 students were born in 2009. All students exhibited typical development. Information such as the distribution of the gender of the students in the study and control groups, demographic properties of their parents, number of children in the household, socio-economic level of the parents was similar.

\subsection{Data Collection Instruments}

The following data collection instruments were used to collect the required data in this study:

\subsection{Personal Information Form}

The form included personal information of the participating students such as gender, age, order of birth, number of children in the household, family structure, household income, mother's age, father's age, mother's education level, father's education level, mother's occupation, and father's occupation. This form was developed by the author and filled by the parents of the children in the study and control groups. The form was sent to the families and collected by the classroom teachers and school administration.

\subsection{Social Adaptation and Skills Scale}

The Social Adaptation and Skills Scale, which was developed by Kandir and adapted to and tested for validity and reliability for pre-school children by Işık (2007), was used in the present study. The scale includes two factors of social adaptation and social maladaptation. The social adaptation subtest includes 17 items that assess the skills related to communication, making friends, empathy, sympathy, cooperation, solving the problems with their peers, helping people around them, tolerance, being in peace with the environment, and obeying the rules. The social maladaptation test includes 8 items that assess skills, such as fighting, interrupting others, complaining about the rules and the life, harming the environment, being angry, and being influenced by friends who do not obey the rules. The Social Adaptation and Skill Scale are filled by the relatives (mother, father or teacher) of children between 4 and 11 years of age. Social adaptation and maladaptation subtests of the scale are both 3-point Likert type scales, scored as "always" (3 points), "sometimes" ( 2 points), "never" (1 point). To determine the study validity, the views of five pre-school education experts were obtained. Mode, median, maximum and minimum values were calculated based on the expert feedback. It was determined that the values each item in the Social Adaptation and Skill Survey received from the experts varied between 1 and 5 and mod and median values varied between 4 and 5 . The results of the factor analysis conducted on Social Adaptation and Skill Scale demonstrated that the Kaiser-Meyer-Olkin (KMO) value was 0.88, Bartlett value was $2930.99(p=0.000<0.05)$. Based on the Basic Component Analysis results, it was determined that the factor loads values were concentrated in two factors and the factor load values of the 25 scale items were 0.509 and above. These findings demonstrated the applicability of factor analysis and that there were correlations among the items. The reliability coefficients for the single application social adaptation subtest were $\alpha=.93$, for first quasi-test, it was .90 , for the second quasi-test, it was .88 and Spearman Brown two quasi-test correlation was .84 . The reliability coefficients for the social maladaptation subscale were $\alpha=$ 0.83 , for first quasi-test, it was .72, for the second quasi-test, it was .68 and Spearman Brown two quasi-test correlation was 0.85 . These findings demonstrated that the reliability of the scale was high (Isik, 2007).

\subsection{Data Collection}

Social Adoption and Skills Scale were applied to 50 students (25 in the study group and 25 in the control group) attending the Civil Servants Kindergarten in Malatya province central district during the 2013-2014 academic year between September 27, 2013 and October 4 2013, after the necessary approval was obtained. The scale was completed by the teacher for each child as the pretest. Detailed instructions were provided for the teachers about the scales and it was observed that they had a supportive 
approach towards the study. At the same time, Personal Information Forms were also sent to the parents of the students in the study and control groups and necessary instructions were communicated about filling the forms. The completed Personal Information Forms were returned by the parents and were delivered to the researcher by the classroom teacher.

After the pretest was applied, the Peaceful Life Skills Education Program was instructed to the children in the study group between October 4, 2013 and December 27, 2013 (12 weeks) by the author one day a week, during the whole learning process. Peaceful Life Skills Education Program was not instructed to the children in the control group, however they continued their conventional training. In the study group, the training material and environment were prepared by the researcher every week before the instruction. Preliminary information was provided for the children about the activities that would be conducted on the day of the instruction.

After the implementation of the Peaceful Life Skills Education Program for 12 weeks, Social Adaptation and Skills Scale was reapplied to 50 children in the study and control groups under the same conditions as the pretest by the teachers between December 27, 2013 and January 3, 2014.

\subsection{Empirical Process}

In the Peaceful Life Skills Education Program, activities to develop the skills related to recognition of emotions, development of self-esteem, communication, empathy, respect for differences, anger control, conflict resolution, cooperation, love of nature, and peace. The education program was initiated on October 4, 2013 and ended on December 27, 2013. It was instructed by the author once a week, during the whole learning process. Materials such as pictures, stories, emotion cards, toys, puppets, photographs projected from a projector, dolls with identifications, various experimental materials, etc. were used in the instruction. The program included activities such as storytelling, dramatization, creative drama, games, music, arts, native language, experiments, examination, etc. The methods of narration, explanation, discussion, question and answer, observation, examination were utilized.

Before the program, interviews were conducted with the classroom teacher to inform the teacher about the education program and necessary instructions were given to prevent the disruption of the student attendance in the program. The teachers were asked to refrain from discussing the applications in the classroom to maintain external validity. Children, who were not able to attend in the program for any reason during the implementation of the education program, were compensated on subsequent days.

The author organized the training environment for each activity before the instruction of the study group. The classroom layout, necessary equipment and materials were organized by the author before each activity. Furthermore, during the application, photographs of the activities were also taken. The participation of all children in the activities was ensured and when necessary, the activities were applied in small and large groups. After the instruction of daily education program, an assessment was conducted with the children and they were given the opportunity to comment on the application. The next day, the previous applications were reevaluated and repeated before moving on to the next activity.

\subsection{Data Analysis}

The independent variable in the study was the Peaceful Life Skills Education Program. Dependent study variables were social adaptation and skill scores. Study and control group pretest and posttest scores were analyzed with SPSS software. When normal distribution was available, independent group's t-test (Student t-test) parametric statistics was used and Mann Whitney U test was used for independent groups with a non-normal distribution. The study results were interpreted at the significance level of .05. The Wilcoxon Signed Rank Test was used to compare the pretest and posttest scores of the children in the study group and the pretest and posttest scores of the children in the control group.

\section{Findings}

\subsection{Findings on the Change that Occurred Between Social Adaptation and Skills of the Students in Study and Control Groups}

These include the findings on the changes in the social adaptation and skills of children who participated and did not participate in the Peaceful Living Skills Education Program.

Table 1. The Results of the t-test Conducted on the Mean Social Adaptation and Skills Scale Pretest Scores of Children in the Study and Control Groups

\begin{tabular}{|c|c|c|c|c|c|c|}
\hline Pretest & $\mathbf{n}$ & $\bar{X}$ & $\mathbf{S}$ & sd & t & $\mathbf{p}$ \\
\hline Study & 25 & 55,92 & 8,15 & \multirow{2}{*}{48} & \multirow{2}{*}{$-0,961$} & \multirow{2}{*}{,342 } \\
\hline Control & 25 & 58,32 & 9,45 & & & \\
\hline
\end{tabular}

Table 2. The Results of the Mann-Whitney U-Test Conducted on the Mean Social Adaptation and Skills Scale Posttest Scores of Children in the Study and Control Groups

\begin{tabular}{|c|c|c|c|c|c|c|c|c|c|}
\hline Posttest (Total) & $\mathbf{n}$ & $\bar{X}$ & Median & Min. & Max. & s.d & Rank mean & U & p \\
\cline { 1 - 7 } Study & 25 & 66,48 & 67,00 & 54,00 & 74,00 & 4,36 & 31,96 & \multirow{2}{*}{151,000} & \multirow{2}{*}{002} \\
\hline Control & 25 & 60,96 & 63,00 & 43,00 & 71,00 & 7,39 & 19,04 & & \\
\hline
\end{tabular}


Table 1 demonstrates that the mean score of the children in the study group was 55.92, and the mean score of the children in the control group was 58.32. Based on the independent groups $t$ test results, it was determined that there was no significant difference between Social Adaptation and Skill Scale pretest mean scores $(t=-0,961$, $p>0,05)$ of children in the study and control groups. Thus, it can be stated that the children in the study and control groups had similar traits before the training.

Table 2 demonstrates that the mean posttest score of the children in the study group was 66.48 and that of the control group was 60.96. The Mann Whitney U Test was conducted to compare the posttest scores of the children in the study and control groups. It was found that the difference between the posttest scores of the children in the study and control groups was significant favoring the study group ( $\mathrm{U}=151,000, \mathrm{p}<0.05)$. Accordingly, the change observed in social adaptation and skill scores of children who participated in the Peaceful Life Skills Training Program after the program was different from the scores of the children in the control group. The scores of the children in the study group were higher than the scores of the children in the control group. This suggested that the education program was effective in supporting social adaptation and skills.

\subsection{Findings on the Variations in the Scores of the Students in the Study and Control Groups}

The third sub-problem was related to the determination of whether the social adaptation and skills of the students in the group where the Peaceful Living Skills Education Program was implemented and, in the group, where the Peaceful Living Skills Education Program was not implemented significantly improved. The related problem cases were tested and presented in the tables below.

The results of the Wilcoxon Signed Ranks Test on whether there was a significant difference between the social adaptation and skills of the children in the study group before and after the experiment are presented in Table 3. The analysis results demonstrated that there was a significant difference between the pretest and posttest scores of the children participating in the study $(z=4,375$, $p<.05)$. When the rank order and sum of the score differences are considered, it was observed that the difference favored the positive rank, in other words, the posttest score. These findings demonstrated that the organized education program had a significant effect on improving the social adaptation and skills of the children.

Table 3. The Results of the Wilcoxon Signed Ranks Test Conducted on the Total and Sub-Dimensions of the Social Adaptation and Skills Scale Pretest and Posttest Scores of the Children in the Study Group

\begin{tabular}{|c|c|c|c|c|c|c|}
\hline Pretest-Posttest & & $\mathbf{n}$ & Mean rank & Total rank & $\mathbf{z}$ & $\mathbf{p}$ \\
\hline \multirow{3}{*}{ Social Adaptation } & Negative rank & 0 &, 00 & .00 & \multirow{3}{*}{4,296} & \multirow{3}{*}{, 000} \\
\hline & Positive rank & 24 & 12,50 & 300,00 & & \\
\hline & Equal & 1 & & & & \\
\hline \multirow{3}{*}{ Social Maladaptation } & Negative rank & 0 &, 00 &, 00 & \multirow{3}{*}{4,117} & \multirow{3}{*}{, 000} \\
\hline & Positive rank & 22 & 11,50 & 11,50 & & \\
\hline & Equal & 3 & & & & \\
\hline \multirow{3}{*}{ Total } & Negative rank & 0 & 00 &, 00 & \multirow{3}{*}{4,375} & \multirow{3}{*}{, 000} \\
\hline & Positive rank & 25 & 13,00 & 325,00 & & \\
\hline & Equal & 0 & & & & \\
\hline
\end{tabular}

Table 4. The Results of the Wilcoxon Signed Ranks Test Conducted on the Total and Sub-Dimensions of the Social Adaptation and Skills Scale Pretest and Posttest Scores of the Children in the Control Group

\begin{tabular}{|c|c|c|c|c|c|c|}
\hline Pretest - Posttest & & $\mathbf{n}$ & Mean rank & Total rank & $\mathbf{z}$ & $\mathbf{p}$ \\
\hline \multirow{3}{*}{ Social Adaptation } & Negative rank & 3 & 4,00 & 12,00 & \multirow{3}{*}{3,375} & \multirow{3}{*}{, 001} \\
\hline & Positive rank & 16 & 11,13 & 178,00 & & \\
\hline & Equal & 6 & & & & \\
\hline \multirow{3}{*}{ Social Maladaptation } & Negative rank & 5 & 6,20 & 31,00 & \multirow{3}{*}{2,176} & \multirow{3}{*}{, 030} \\
\hline & Positive rank & 12 & 10,17 & 122,00 & & \\
\hline & Equal & 8 & & & & \\
\hline \multirow{3}{*}{ Total } & Negative rank & 3 & 5,00 & 15,00 & \multirow{3}{*}{3,515} & \multirow{3}{*}{, 000} \\
\hline & Positive rank & 18 & 12,00 & 216,00 & & \\
\hline & Equal & 4 & & & & \\
\hline
\end{tabular}


It was observed that there was a statistically significant difference between Social Adaptation and Skill Scale pretest and posttest scores of the children in the control group who were only instructed with the activities in the Pre-school Education Program without any further interventions. This difference was in favor of the posttest. In other words, it was observed that the social adaptation and skills of these children increased as well. However, it is not possible to argue that this increase was completely positive, as was the case with the children in the study group. There was no change in the negative rank in the study group, however changes in the negative rank were observed in the control group. Thus, it can be suggested that the control group students improved due to other reasons such as the implementation of the Pre-School Education Program activities, family factor, interaction with the environment, however the development was not as clear as the students who were exposed to peace education.

\section{Discussion and Conclusions}

The present study aimed to develop children's social adaptation and skills. A pretest was conducted at the beginning of the study and it was observed that the study and control group students received similar scores and there was no significant difference between their pretest mean scores ( $p>.05)$. Posttest results demonstrated that the whole Social Adaptation and Skills Scale scores increased significantly in the study group when compared to the control group $(p<.05)$. It was found that the level of social adaptation and skills of the children in the study group who participated in the program was higher when compared to the children in the control group, who did not participate in the program.

The abovementioned study findings were consistent with several studies in the literature. In a study that investigated the effect of the character education program developed for 5-6 year-old children, Gökçek (2007) found that there were positive developments in the behavior of respect, responsibility, self-esteem, leadership, charity, courtesy and patience. Furthermore, in the same study, parents indicated that pre-school education helped develop a positive character. In the present study, where the values scrutinized in the study by Gökçek were also included, similar positive feedback was obtained and it was observed that the children achieved positive character traits.

According to Petroska-Beska (1997, cited by Tapan, 2006), the main objective of peace education focuses on behavior change and acquisition of skills. The life skills that assist the individual in adaptation to life can be summarized as follows: self-awareness - empathy, communication - interpersonal relationships, decision making-problem solving, creative thinking-critical thinking, recognizing feelings - recognizing stress. The skills that reflect the strengths of peace education are communication, empathy, anger control, cooperation, critical thinking, collaborative negotiation and mediation. Behaviors that demonstrate the strong influence of peace education are voluntary interaction with others, accepting similarities and respecting differences, overcoming the prejudices. In the implemented education program, these skills and behaviors were especially targeted, and the program aimed the children to acquire the skills they can use throughout their lives. The study findings demonstrated that the children acquired the abovementioned positive skills and behavior as a result of the instructed program. These findings demonstrated that the objective and the strengths of the peace education as defined by Petroska-Beska can be acquired during the preschool period.

The findings of the present study were also consistent with a study conducted by Sağkal (2011). Sağkal (2011) studied the effect of a 12 weeks long peace education program on the aggressive tendencies and empathy levels of $6^{\text {th }}$ grade primary school students. Study findings demonstrated that the aggression tendency of the students decreased, and their empathy levels increased. It was also found that the students' awareness on the concept of peace, interpersonal communication and conflict resolution skills, their relationships with their peers, family, and teachers were improved and a positive atmosphere became prevalent in the classroom and school environment. These positive findings were consistent with the findings of the present study. In other words, the peace education programs where peace skills are prioritized result in positive changes among the students.

Another study, where positive developments were observed in the study group, was conducted by Tapan (2006), who investigated the changes in conflict resolution skills of two groups' of $8^{\text {th }}$ grade students who attended and did not attend peace education. The Peace Education Program that included eleven activities aimed to encourage students to use I language, acquire effective listening, anger control, conflict resolution and mediation skills. As a result, it was found that these skills improved in the study group students. The results of the interviews conducted with children also demonstrated that the study group could explain the conflicts with examples, while the control group approached the conflict with a negative description and often exhibited violent behavior during conflicts. It was emphasized that activities promoting peaceful skills, which emphasized the concept of peace, reduced conflicts and promoted positive behavior.

Several studies in the literature on development of social skills, character, values education, moral development and peace education emphasized that education should be started during early ages in order for children to acquire positive behavior. Retention of positive behavior and universal values is more feasible with special education during early ages, and this is considered to be a promising development for avoiding possible violence and conflict 
situations in the future. Peace education programs and social skills programs are frequently used for the development of these behaviors. In a study conducted by Martin (2003), the preschool social skills program and the primary school program were compared. Study results demonstrated that social skills education would improve social skills and peer acceptance starting from the preschool (Cited by Çelik, 2007).

Children who exhibit behavior such as communication with peers, making friends easily, empathy skills, expression of emotions and ideas, cooperation, tolerance, problem solving and following the rules can be considered as socially adapted. It is known that children who acquire these skills at an early age are more likely to be able to be accepted by their peers easily, could be academically successful and more adaptive and balanced individuals in adulthood (Çetin, Alpa-Bilbay and Albayrak-Kaymak, 2002). The program, which is applied to the study group in the present study, included activities that aimed to increase children's social adaptation skills and to reduce social maladaptation. The significant difference that favored the study group indicated that children acquired these social skills that they should earn at an early age. It was observed that the program promoted empathy, cooperation, self-esteem, etc. of preschool students, and increased their awareness about these values.

Analysis of study findings demonstrated that for the social-emotional development of the children and the development of their social skills, they should exhibit adaptation behavior, recognize emotions, develop friendships, acquire empathy skills, respect diversity, gain awareness on anger control and conflict resolution and become individuals who respect the nature and the environment. All these requirements should be addressed at early ages and the function of education to teach children how to be peaceful is important to create a conflict-free society. The study results revealed the significance of pre-school education, peer interaction, use of activities that promote recognition of emotions, problem-solving skills, the use of programs that focus on peace skills, and the principle of learning by doing.

In conclusion, in the present study, the implemented program was effective on the study group students based on the whole scale and on the scale sub-dimensions. Thus, it can be suggested that the Peaceful Life Skills Education Program provides significant contributions to the development of social adaptation and skills of pre-school children, also based on the previous similar studies.

\section{REFERENCES}

[1] Akgün, S. ve Araz, A. (2010). Anlaşmazlıklarımızı çözebiliriz: Bir çatışma çözümü eğitim programı tanıtımı. Doğuş Üniversitesi Dergisi, 11(1), 1-17.
[2] Aktaş, Ö. ve Safran, M. (2013). Evrensel bir değer olarak barış ve barış eğitiminin tarihçesi. Türkiye Sosyal Araştırmalar Dergisi, 17(2), 131-150.

[3] Çelik, N. (2007). Sosyal beceri ĕgitiminin ilköğretim ögrencilerinin sosyal uyum düzeylerine etkisi. Yüksek Lisans Tezi, Dokuz Eylül Üniversitesi Eğitim Bilimleri Enstitüsü, İzmir.

[4] Çetin, F., Alpa-Bilbay, A. ve Albayrak-Kaymak, D. (2002). Araştırmadan uygulamaya çocuklarda sosyal beceriler grup eğitimi. (2. Bask1). İstanbul: Epsilon Yayınc1lık.

[5] Demir, S. (2011). Türkiye'de barış eğitimine bakış: Tanımlar, zorluklar, öneriler: Nitel inceleme. Kuram ve Uygulamada Ĕgitim Bilimleri, 11(4), 1727-1745.

[6] Dinçer, F. (2012). Peaceful skills: Anatolian Sufi Verses and the peace education. Uludă̆ Üniversitesi Eğitim Fakültesi Dergisi, 25(1), 35-50.

[7] Durualp, E. (2009). Anasinifina devam eden altı yaş çocuklarının sosyal uyum ve becerilerine oyun temelli sosyal beceri eğitiminin etkisinin incelenmesi: Çankırı örneği. Doktora Tezi, Ankara Üniversitesi Fen Bilimleri Enstitüsü, Ankara.

[8] Dündar, S. (2007). Alternatif eğitimin felsefi temelleri ve alternatif okullardaki uygulamalar. Yüksek Lisans Tezi, Marmara Üniversitesi Eğitim Bilimleri Enstitüsü, İstanbul.

[9] Ekinci, B. (2010). Diyarbakır'ın Eğil ilçesi ve köylerinde ilkögretim kademesinde görev yapan ögretmenlerin benlik saygıları, çatışma stilleri ve empati düzeylerine "Barış Ĕ̈itimi” programının etkisinin incelenmesi. Yüksek Lisans Tezi, Gazi Üniversitesi Eğitim Bilimleri Enstitüsü, Ankara.

[10] Ekmişoğlu, M. (2007). Erken çocukluk döneminde farklılıklara saygı kavramı hakkında öğretmen görüşlerinin incelenmesi ve farklılıklara saygı ölçeğinin geçerlik ve güvenirlik çalışması. Yüksek Lisans Tezi, Çanakkale Onsekiz Mart Üniversitesi Sosyal Bilimler Enstitüsü, Çanakkale.

[11] Gökçek, B. S. (2007). 5-6 yaş çocukları için hazırlanan karakter eğitimi programının etkisinin incelenmesi. Yüksek Lisans Tezi, Marmara Üniversitesi Eğitim Bilimleri Enstitüsü, İstanbul.

[12] Goleman, D. (2007). Sosyal zeka insan ilişkilerinin yeni bilimi. (3. Basım). (Çev: O. Ç. Deniztekin). İstanbul: Varlık Yayınları.

[13] Işık, M. (2007). Anasınıfina devam eden beş-altı yaş çocuklarına sosyal uyum ve beceri ölçeğinin uyarlanması ve uygulanması. Yüksek Lisans Tezi, Gazi Üniversitesi Eğitim Bilimleri Enstitüsü, Ankara.

[14] Johnson, R. T. and Johnson, D. W. (2002). Teaching student to be peacemakers: A meta-analysis. Journal of Research in Education, 12(1), 25-39.

[15] Johnson, D. W. and Johnson, R. T. (2003). Controversy and peace education. Journal of Research in Education, 13(1), 79-91.

[16] Pınar, M. ve Acar, E.A.(2012, 1-2 Aralık). Okul öncesinde barış dili. III. Okul Öncesi Eğitimi Sempozyumu, İstanbul.

[17] Ritchie, J., Lockie, C. ve Rau, C. (2011). He Tatau Pounamu: Considerations for an early childhood peace curriculum 
focusing on criticality, indigeneity and an ethic of care, in Aotearoa New Zealand. Journal of Peace Education, 8(3), 333-352.

[18] Sağkal, A. S. (2011). Barış eğitimi programının ilköğretim 6. sını ögrrencilerinin saldırganlık eğilimleri, empati düzeyleri ve barışa ilişsin görüşleri üzerindeki etkisinin incelenmesi. Yüksek Lisans Tezi, Dokuz Eylül Üniversitesi Eğitim Bilimleri Enstitüsü, İzmir.

[19] Sağkal, A. S., Türnüklü, A. ve Totan, T. (2012). Kişilerarası barıș için empati barıș eğitiminin empati becerilerine etkileri. Kuram ve Uygulamada Eğitim Bilimleri, 12(2), 1447-1460.

[20] Smith, J. T. (2013). Erken çocukluk dönemi gelişimi: Tarihsel yaklaşımlar ve araştırmalar. B. Akman (Çeviri Ed.). M. Buldu (Çevirmen). Erken çocukluk döneminde gelişim çok kültürlü bir bakış açısı - Early childhood development a multicultural perspective içinde (s.14-33). Ankara: Nobel Akademik Yayıncılık. (Orijinal basım yılı 2010).

[21] Smith, J. T. (2013). Çocuk gelişimi kuramları. B. Akman (Çeviri Ed.). M(Çevirmen). Erken çocukluk döneminde gelissim çok kültürlü bir bakış açısı - Earlychildhood development a multicultural perspective içinde (s. 34-63). Ankara: Nobel Akademik Yayıncılık. (Orijinal basım yılı 2010).

[22] Strayer, J. and Roberts, W. (2004). Empathy and observed anger and aggression in five years old. Social Development, $13(1), 1-13$.

[23] Tapan, Ç. (2006). Barış eğitimi programının öğrencilerin çatışma çözme becerileriüzerindeki etkilerinin incelenmesi. Yayımlanmamış Yüksek Lisans Tezi, Dokuz Eylül Üniversitesi Eğitim Bilimleri Enstitüsü, İzmir.

[24] Üner, E. (2011). Okul öncesi eğitim programındaki 36-72 aylık çocuklara farklılıklara saygl eğitimi kazandırmanın ögrretmen görüşleri doğrultusunda değerlendirilmesi.http://temelegitim.toob.org.tr/files/pdf/IV Temel_Egitim_Sonuc_Bildirgesi.pdf (Siteden Alınan Tarih: 15.03.2014) Türkiye Özel Okullar Birliği Derneği Eğitimde Farklılıklara Saygı ve Uygulamaları Sonuç Bildirgesi 7-8 Aralık 2013, İstanbul. 